\title{
Diversity of Virulence in Phytophthora parasitica on Tobacco, as Reflected by Nuclear RFLPs
}

\author{
V. Colas, I. Lacourt, P. Ricci, F. Vanlerberghe-Masutti, P. Venard, A. Poupet, and F. Panabières
}

First, second, third, fifth, sixth, and seventh authors: Institut National de la Recherche Agronomique (INRA), Station de Botanique et de Pathologie Végétale, 62 Boulevard du Cap, BP 2078, F-06606 Antibes Cedex, France; fourth author: INRA, Laboratoire de Biologie des Invertébrés, 123 Boulevard Francis Meilland, BP 2078, F-06606 Antibes Cedex, France.

Current address of I. Lacourt: Centro di Studio Sulla Micologia del Terreno del CNR, c/o Dipartimento di Biologia Vegetale dell'Universita di Torino, viale P. A. Mattioli, 25. 10125, Torino, Italy.

Accepted for publication 29 November 1997.

\begin{abstract}
Colas, V., Lacourt, I., Ricci, P., Vanlerberghe-Masutti, F., Venard, P., Poupet, A., and Panabières, F. 1998. Diversity of virulence in Phytophthora parasitica on tobacco, as reflected by nuclear RFLPs. Phytopathology 88: 205-212.

A worldwide collection of $P$. parasitica isolates was investigated for the ability to infect tobacco and tomato, as related to elicitin production. Elicitin was produced by all nontobacco isolates, and nonproducing strains all were isolated from tobacco. In addition, producing strains were isolated from tobacco and coexisted with nonproducing $\left(\mathrm{TE}^{-}\right)$strains. Elicitin production generally was associated with low virulence on tobacco and frequent pathogenicity on tomato, whereas $\mathrm{TE}^{-}$isolates generally

were highly virulent and specialized to tobacco. Analysis of both mitochondrial and nuclear DNA restriction fragment length polymorphisms indicated, for the first time, that black shank isolates can be distinguished from other $P$. parasitica isolates on the basis of genetic criteria. Our results suggest that severe black shank is caused by a limited number of $\mathrm{TE}^{-}$strains that have been disseminated by clonal evolution. Mutations in the $\mathrm{TE}^{-}$phenotype seem to have arisen independently in several genetic backgrounds and distinct geographic areas. The fortuitous absence of elicitin production has precluded population replacements in areas of intensive tobacco cultivation. Thus, monitoring the loss of elicitin production in developing tobacco areas should be considered in disease management.
\end{abstract}

The genus Phytophthora exhibits a wide array of host-pathogen interactions. Although all species of this genus are plant pathogens, their host specificity is extremely diverse, ranging from strict specialization, as for $P$. idaei on raspberry (17), to large host ranges, as for $P$. cinnamomi, which parasitizes more than 900 plant species (7). Within P. parasitica Dastur, both situations occur. This species exhibits an overall broad host range, but some isolates are specialized toward a single host, as is the case for tobacco (7). Infection of tobacco by $P$. parasitica causes black shank, by far the most destructive disease in this crop. Despite extensive work within the species $P$. parasitica, the taxonomic position of the isolates from tobacco is still unclear (7). Their artificial inoculation on some alternate hosts has been successful under certain conditions, but tobacco is their sole natural host plant (20). This preference led Tucker (26) to designate the black shank fungus as $P$. parasitica var. nicotianae, a designation that is still largely in use but that has come under sharp criticism (7). In fact, attempts to establish distinct subgroups within $P$. parasitica based on morphological $(27)$ or other features $(9,18,22)$ have failed. Moreover, examination of isozyme patterns (21) and restriction fragment length polymorphisms (RFLPs) of both nuclear and mitochondrial DNA (mtDNA) for a limited set of isolates (9) has revealed a low level of polymorphism in this species. For tobacco the situation is further confused by the large variability of virulence observed among P. parasitica isolates (20) and the occurrence of a disease (termed "brown stem rot" in eastern Africa) that is very similar to black shank but less severe and incited by nonspecialized isolates of $P$. parasitica (13). Therefore, the basis

Corresponding author: F. Panabières; E-mail address: panab@antibes.inra.fr

Publication no. P-1998-0113-01R

(c) 1998 The American Phytopathological Society of host specialization on tobacco still lacks molecular support and remains an open question.

One feature common to all Phytophthora species is secretion of elicitins (23). The 10-kDa proteins act as inducers of defense responses when applied on tobacco plants and protect the plants against subsequent infection by a compatible pathogen, including the black shank fungus (3). As an exception to the rule, some isolates lack elicitin production, and large-scale surveys have revealed that these cultures all belonged to $P$. parasitica and were exclusively black shank isolates $(4,16)$. The hypothesis that the absence of elicitin secretion is a basis for pathogenicity to tobacco is tempting to consider, because elicitins are specifically active on Nicotiana spp. (24). However, the situation is not that simple, because other isolates from tobacco produce elicitin and are virulent on this plant, although to a lesser extent $(4,16)$. Elicitin production, thus, adds to the diversity already recognized in this tobacco pathogen.

To investigate this diversity more precisely, a large collection of isolates from diseased tobacco in various areas of the world has been gathered. Isolates of $P$. parasitica from other host plants have been included for comparison. In a previous study, mtDNA polymorphism was low and related to the geographic origin rather than the host plant (18). In the current study, RFLPs of nuclear DNA were used to analyze the diversity in this collection, and we found that isolates that do not produce elicitins are not randomly distributed and do have particular pathogenic properties. These results provide the first indication that the concept of a tobacco forma specialis within $P$. parasitica may have a genetic basis.

\section{MATERIALS AND METHODS}

Fungal isolates and culture conditions. $P$. parasitica isolates were kept at the Institut National de la Recherche Agronomique (Antibes, France) culture collection and are listed in Table 1. They 
were obtained from various geographic areas with the help of CORESTA (Cooperation Center for Research Relative to Tobacco, Paris). Fungal cultures were grown on malt agar $\left(1 \%: 1 \%\right.$ wt/vol) at $24^{\circ} \mathrm{C}$ in darkness. These isolates were kept in cryogenic storage.

Protein and nucleic acids analyses. Elicitin content evaluation, culture filtrate treatments, sodium dodecyl sulfate-polyacrylamide gel electrophoresis (SDS-PAGE), transfer, and immunodetection were carried out as previously described (19).

Total genomic DNA was extracted from 7-day-old cultures maintained on defined liquid glucose-asparagine medium (12), as described previously (22), except a RNase treatment was added prior to ethanol precipitation. Mitochondrial DNA was purified according to Hwang et al. (14). Mitochondrial haplotypes were determined as previously described (18).

Genomic DNA $(5 \mu \mathrm{g})$ was digested with 25 units of restriction enzyme following the manufacturers' recommendations, and fragments were separated in a $1 \%$ agarose gel in $0.5 \times$ Tris-borateEDTA buffer at $5 \mathrm{~V} \mathrm{~cm}^{-1}$. Alternatively, $1 \times$ Tris-acetate-EDTA buffer was used in overnight electrophoresis at $3 \mathrm{~V} \mathrm{~cm}^{-1}$. Blotting transfer, probe labeling, and hybridization were performed according to standard protocols (25). The final washings that followed the hybridizations were performed twice in $0.2 \times \mathrm{SSC}(1 \times \mathrm{SSC}$ is $0.15 \mathrm{M}$ sodium chloride plus $0.015 \mathrm{M}$ sodium citrate, $\mathrm{pH} 7.0$ ) and $0.1 \%$ SDS for $15 \mathrm{~min}$ at $65^{\circ} \mathrm{C}$.

Nuclear probes were selected from a partial genomic library constructed as follows: genomic DNA from $P$. parasitica was par- tially digested with BamHI and HindIII, ligated into pBluescript $\mathrm{SK}^{-}$vector (Stratagene, La Jolla, Ca), and used to transform Escherichia coli strain DH5 $\alpha$ (Gibco BRL, Bethesda, MD). Each clone was tested for its relative abundance according to standard procedures (25).

Data analysis. The genetic relationships between mitochondrial haplotypes were assessed by the similarity coefficient of Nei and Li. A dendrogram was generated by the unweighted paired-group method, arithmetic mean (UPGMA) algorithm contained in the program package Phylip 3.57 (8). A second approach, which utilized the parsimony method, in which the presence or absence of individual restriction fragments of mtDNA was scored, also was undertaken. The most parsimonious trees were obtained by the branch and bound Dolpenny program included in the Phylip package (8). RFLP signals were qualitatively scored as 0 (absence) or 1 (presence). These data were treated by the factorial analysis of correspondence (FAC) method $(2,11)$, using the PROC CORRESP procedure in the SAS program (SAS Institute, Cary, NC). This method consists of a weighted principal component analysis of a contingency table. It is used to find a low-dimension graphic representation of the association between rows (isolates) and columns (RFLP data) in a Euclidean space. Individuals and variables can be plotted separately or on the same graph. Each point partially contributes to axes determination.

In the current study, two individuals sharing close coordinates for one axis will be closely related based on RFLP signals con-

TABLE 1. Characteristics of the isolates used in this study

\begin{tabular}{|c|c|c|c|c|c|c|c|c|c|c|}
\hline Isolate & $\begin{array}{l}\text { Area } \\
\quad \text { Country }\end{array}$ & Location & Year & Host & $\begin{array}{l}\text { Mating- } \\
\text { type }\end{array}$ & $\mathrm{mtDNA}^{\mathrm{a}}$ & Race & $\begin{array}{l}\text { Stem invasion } \\
\text { on tobacco }^{\mathrm{b}}\end{array}$ & $\begin{array}{l}\text { Virulence } \\
\text { on tomato }^{\mathrm{c}}\end{array}$ & $\begin{array}{l}\text { Parasiticein } \\
\text { production }\end{array}$ \\
\hline & Europe & & & & & & & & & \\
\hline 26 & France & Alpes Maritimes & 1971 & Carnation & A2 & A & $\ldots$ & 14.5 & 0.8 & + \\
\hline 44 & France & Corse & 1972 & Citrus & A1 & A & $\ldots$ & 3.5 & 0 & + \\
\hline 149 & Spain & Unknown & 1975 & Tomato & $\mathrm{A} 2$ & A & $\ldots$ & 22 & 4 & + \\
\hline 384 & Bulgaria & Blagoevgrad & 1991 & Tobacco & A2 & A & 0 & 100.5 & 0 & - \\
\hline 387 & Bulgaria & Kurdjali & 1992 & Tobacco & $\mathrm{A} 2$ & A & 0 & 94 & 0 & - \\
\hline 385 & Bulgaria & Gotse Delchev & 1992 & Tobacco & $\mathrm{A} 2$ & A & 0 & 70 & 0 & + \\
\hline 386 & Bulgaria & Gotse Delchev & 1992 & Tobacco & A2 & A & 0 & 67.5 & 0.8 & + \\
\hline 329 & Greece & Unknown & Unknown & Tobacco & $\mathrm{A} 2$ & A & 1 & 87 & 0 & - \\
\hline 330 & Greece & Unknown & Unknown & Tobacco & $\mathrm{A} 2$ & A & 0 & 48 & 0 & - \\
\hline \multirow[t]{2}{*}{332} & Greece & Unknown & Unknown & Citrus & $\mathrm{A} 2$ & A & $\ldots$ & 11 & 0 & + \\
\hline & N. America & & & & & & & & & \\
\hline 181 & United States & Unknown & Unknown & Tobacco & A2 & A & 1 & 84 & 0 & - \\
\hline 183 & United States & Unknown & Unknown & Tobacco & A2 & A & 0 & 110 & 0 & - \\
\hline 301 & United States & Unknown & Unknown & Tobacco & $\mathrm{A} 1 / \mathrm{A} 2^{\mathrm{d}}$ & A & 1 & 44 & 0 & + \\
\hline 369 & United States & Kentucky & 1986 & Tobacco & A1 & A & 0 & 110 & 0 & - \\
\hline 370 & United States & Kentucky & 1991 & Tobacco & $\mathrm{A} 1 / \mathrm{A} 2^{\mathrm{d}}$ & A & 1 & 100 & 0 & - \\
\hline 371 & United States & Kentucky & 1990 & Tobacco & A2 & A & 0 & 105 & 0 & - \\
\hline 372 & United States & Kentucky & 1990 & Tobacco & A1 & A & 1 & 105 & 0 & - \\
\hline 395 & United States & Georgia & 1990 & Tobacco & A1 & A & 1 & 106 & 0 & - \\
\hline 396 & United States & Georgia & 1989 & Tobacco & A1 & A & 0 & 101.5 & 0 & - \\
\hline 397 & United States & Georgia & 1990 & Tobacco & A1 & A & 0 & 107.5 & 0 & - \\
\hline 398 & United States & Georgia & 1990 & Tobacco & A1 & A & 0 & 106 & 0 & - \\
\hline 399 & United States & Georgia & 1991 & Tobacco & A1 & A & 0 & 105 & 0 & - \\
\hline 400 & United States & Georgia & 1991 & Tobacco & A1 & A & 1 & 111 & 0 & - \\
\hline 401 & United States & Georgia & 1991 & Tobacco & A1 & A & 1 & 112 & 0 & - \\
\hline 402 & United States & Georgia & 1991 & Tobacco & $\mathrm{A} 2$ & A & 1 & 106 & 0 & - \\
\hline 403 & United States & Georgia & 1991 & Tobacco & A1 & A & 1 & 107 & 0 & - \\
\hline 404 & United States & Georgia & 1991 & Tobacco & A1 & A & 0 & 104.5 & 0 & - \\
\hline 428 & United States & North Carolina & 1990 & Tobacco & A1 & A & 0 & 96 & 0 & - \\
\hline 429 & United States & North Carolina & 1993 & Tobacco & A1 & A & 0 & 118.5 & 0 & - \\
\hline 430 & United States & North Carolina & 1993 & Tobacco & A2 & $\mathrm{D}^{\prime \prime \prime}$ & 0 & 98 & 0 & - \\
\hline 431 & United States & North Carolina & 1993 & Tobacco & $\mathrm{A} 2$ & $\mathrm{D}^{\prime \prime \prime}$ & 0 & 83 & 0 & - \\
\hline \multirow[t]{2}{*}{432} & United States & North Carolina & 1993 & Tobacco & A2 & A & 0 & 28 & 0.8 & + \\
\hline & \multicolumn{10}{|c|}{ C. America and W. Indies } \\
\hline 324 & Cuba & Pinar del Rio & 1985 & Tobacco & A1 & A & 0 & 98 & 0 & - \\
\hline 325 & Cuba & La Habana & 1984 & Tobacco & A1 & A & 0 & 91 & 0 & - \\
\hline \multirow[t]{2}{*}{326} & Cuba & La Habana & 1987 & Tobacco & A1 & A & 0 & 95 & 0 & - \\
\hline & & & & & & & & & \multicolumn{2}{|c|}{ (continued on next page) } \\
\hline
\end{tabular}

a Mitochondrial groups were obtained as described by Lacourt et al. ( 18).

${ }^{\mathrm{b}}$ Length of brown lesions in millimeters.

c Notation of symptoms is described in text.

${ }^{\mathrm{d}}$ Oospore production was observed after pairing with both $\mathrm{A} 1$ and $\mathrm{A} 2$ isolates but not in pure culture. 
tributing to the determination of that axis. In a preliminary analysis, four isolates $(370,371,372$, and 395) introduced a distortion in the overall representation because they had unique additional RFLP bands. FAC was repeated, with these four isolates included as additional individuals. Variables other than nuclear RFLPs (mitochondrial haplotype, tobacco origin, and elicitin production) were introduced as additional variables that did not affect the results of FAC. This analysis was limited to the first five axes, resulting in an assessment of $55.4 \%$ of the total variability. RFLP data and nuclear probes are available upon request.

Pathogenicity assays on tobacco. Stem inoculations. Stem inoculations of 2-month-old tobacco plants (N. tabacum cv. Samsun) were performed as described previously (4). Briefly, two mycelial plugs were applied to the cut surfaces of decapitated stems. Invasion was estimated as the length of the brown lesion produced by each isolate. The mean of two independent measures was used as the final notation. The measures obtained for the same isolate always ranged within a $10-\mathrm{mm}$ interval.

Root inoculations. Rooted plantlets of N. tabacum cv. Xanthinc were propagated in vitro by monthly transfers of nodal cuttings on the following solid medium: inorganic salts of Murashige and Skoog medium, with $\mathrm{NH}_{4} \mathrm{NO}_{3}$ reduced to $800 \mathrm{mg} \mathrm{liter}^{-1}$, myoinositol at $100 \mathrm{mg} \mathrm{liter}^{-1}$, vitamins (calcium pantothenate, thiamin $\mathrm{HCl}$, nicotinic acid, pyridoxine, and cysteine $\mathrm{HCl}$ at $1 \mathrm{mg} \mathrm{liter}^{-1}$ each), sucrose at $15 \mathrm{~g} \mathrm{liter}^{-1}$, and agar at $7 \mathrm{~g} \mathrm{liter}^{-1}, \mathrm{pH}$ 5.8. To assay pathogenicity, 25-mm-long terminal cuttings (the apical bud and two leaves) were transferred to plastic bridges on the same medium without agar and rooted for 1 month. Inoculation was performed by replacing the growth medium with $20 \mathrm{ml}$ of sterile water to which 100 zoospores had been added. The inoculation of each isolate was repeated three times. The plants were kept in a growth chamber at $23^{\circ} \mathrm{C}$, with $16 \mathrm{~h}$ daily illumination at $40 \mathrm{mM} \cdot \mathrm{m}^{-2} \cdot \mathrm{s}^{-1}$, and observed each day for 2 weeks.

Inoculation of tomato plants. Ten-day-old plants (Lycopersicon esculentum cv. Marmande) were removed from the soil, and their roots were carefully washed. The root tips were cut, and five plantlets were placed on water-soaked Whatman No. 1 paper (Whatman, Maidstone, England, U.K.), that covered half a petri dish $(10 \mathrm{~cm}$ in diameter). A mycelium plug (1 cm diameter) was placed on the cut extremity of the root system of each plantlet. For each experiment, a positive control was made with the very aggressive tomato isolate 149. Two negative controls also were included: five plantlets were treated as previously described, except they were not inoculated, and five plantlets were inoculated by isolate 183 , which is not pathogenic on tomato. A notation ranging from 0 to 4 was attributed to each plantlet, depending on the symptoms observed after 1 week (i.e., $0=$ no symptoms; $1=$ stem brown but not rotted; $2=$ half of the stem rotted; $3=$ entire stem and part of the leaves rotted; and $4=$ plant dead). The average of five repeats was calculated as a final notation for each isolate.

Race determination. Two tobacco isogenic lines (46-8 and 46-10) were used to characterize races 0 and 1 among tobacco isolates.

TABLE 1. (continued from preceding page)

\begin{tabular}{|c|c|c|c|c|c|c|c|c|c|c|}
\hline Isolate & $\begin{array}{l}\text { Area } \\
\text { Country }\end{array}$ & Location & Year & Host & $\begin{array}{l}\text { Mating- } \\
\text { type }\end{array}$ & $\mathrm{mtDNA}^{\mathrm{a}}$ & Race & $\begin{array}{l}\text { Stem invasion } \\
\text { on tobacco }^{\mathrm{b}}\end{array}$ & $\begin{array}{l}\text { Virulence } \\
\text { on tomato }^{c}\end{array}$ & $\begin{array}{c}\text { Parasiticein } \\
\text { production }\end{array}$ \\
\hline 347 & Cuba & Unknown & Unknown & Tobacco & A1 & A & 0 & 106 & 0 & - \\
\hline 348 & Cuba & Unknown & Unknown & Tobacco & A1 & A & 0 & 96 & 0 & - \\
\hline 118 & Cuba & Unknown & Unknown & Citrus & A1 & $E^{\prime}$ & $\ldots$ & 10 & 0 & + \\
\hline 362 & Cuba & Unknown & Unknown & Cocoa & $\mathrm{A} 2$ & $E^{\prime \prime}$ & $\ldots$ & 23 & 0 & + \\
\hline 364 & Cuba & Unknown & Unknown & Cocoa & A2 & $E^{\prime \prime}$ & $\ldots$ & 31.5 & 0 & + \\
\hline 254 & Martinique & Unknown & 1983 & Eggplant & A1 & A & $\ldots$ & 30 & 1.2 & + \\
\hline $\begin{array}{l}413 \\
408 \\
409 \\
410 \\
411\end{array}$ & $\begin{array}{l}\text { S. America } \\
\text { Colombia } \\
\text { Argentina } \\
\text { Argentina } \\
\text { Argentina } \\
\text { Argentina }\end{array}$ & $\begin{array}{l}\text { Valle del Cauca } \\
\text { Jujuy } \\
\text { Jujuy } \\
\text { Jujuy } \\
\text { Jujuy }\end{array}$ & $\begin{array}{l}1993 \\
1993 \\
1993 \\
1993 \\
1993\end{array}$ & $\begin{array}{l}\text { Tobacco } \\
\text { Tobacco } \\
\text { Tobacco } \\
\text { Tobacco } \\
\text { Tobacco }\end{array}$ & $\begin{array}{l}\mathrm{A} 2 \\
\mathrm{~A} 2 \\
\mathrm{~A} 2 \\
\mathrm{~A} 2 \\
\mathrm{~A} 2\end{array}$ & $\begin{array}{l}\mathrm{A} \\
\mathrm{D}^{\prime \prime \prime} \\
\mathrm{D}^{\prime \prime \prime} \\
\mathrm{D}^{\prime \prime \prime} \\
\mathrm{D}^{\prime \prime \prime}\end{array}$ & $\begin{array}{l}1 \\
0 \\
0 \\
0 \\
0\end{array}$ & $\begin{array}{l}119 \\
82.5 \\
99 \\
96 \\
87.5\end{array}$ & $\begin{array}{l}0 \\
0 \\
0.6 \\
1.2 \\
1\end{array}$ & $\begin{array}{l}- \\
+ \\
+ \\
+ \\
+\end{array}$ \\
\hline $\begin{array}{l}115 \\
376 \\
377 \\
378 \\
379 \\
380 \\
381 \\
373 \\
374 \\
375\end{array}$ & $\begin{array}{l}\text { Africa } \\
\text { Congo } \\
\text { Zimbabwe } \\
\text { Zimbabwe } \\
\text { Zimbabwe } \\
\text { Zimbabwe } \\
\text { Zimbabwe } \\
\text { Zimbabwe } \\
\text { Transvaal } \\
\text { Transvaal } \\
\text { Transvaal }\end{array}$ & $\begin{array}{l}\text { Unknown } \\
\text { Mutepatepa } \\
\text { Muurwi District } \\
\text { Mutepatepa } \\
\text { Karoî District } \\
\text { Karô̂ District } \\
\text { Karoî District } \\
\text { Alkmaar } \\
\text { Heidelberg } \\
\text { Rustenburg }\end{array}$ & $\begin{array}{c}\text { Unknown } \\
1985 \\
1991 \\
1991 \\
1992 \\
1992 \\
1992 \\
1992 \\
1992 \\
1992\end{array}$ & $\begin{array}{l}\text { Citrus } \\
\text { Tobacco } \\
\text { Tobacco } \\
\text { Tobacco } \\
\text { Tobacco } \\
\text { Tobacco } \\
\text { Tobacco } \\
\text { Tobacco } \\
\text { Tobacco } \\
\text { Tobacco }\end{array}$ & $\begin{array}{l}\text { A1 } \\
\text { A1 } \\
\text { A1 } \\
\text { A1 } \\
\text { A1 } \\
\text { A1 } \\
\text { A1 } \\
\text { A2 } \\
\text { A2 } \\
\text { A2 }\end{array}$ & $\begin{array}{l}\mathrm{A} \\
\mathrm{A} \\
\mathrm{A} \\
\mathrm{A} \\
\mathrm{A} \\
\mathrm{A} \\
\mathrm{A} \\
\mathrm{D}^{\prime \prime \prime} \\
\mathrm{D}^{\prime \prime \prime} \\
\mathrm{D}^{\prime \prime \prime}\end{array}$ & $\begin{array}{l}\ldots \\
0 \\
0 \\
0 \\
\mathrm{nt} \\
\mathrm{nt} \\
0 \\
1 \\
1 \\
1\end{array}$ & $\begin{array}{l}10.5 \\
20 \\
26 \\
87 \\
27 \\
37 \\
32 \\
107 \\
120 \\
110\end{array}$ & $\begin{array}{l}0 \\
0 \\
4 \\
2.2 \\
2.4 \\
2.2 \\
4 \\
0 \\
0 \\
0\end{array}$ & $\begin{array}{l}+ \\
+ \\
+ \\
+ \\
+ \\
+ \\
+ \\
- \\
- \\
-\end{array}$ \\
\hline $\begin{array}{l}391 \\
388 \\
365 \\
366 \\
367\end{array}$ & $\begin{array}{l}\text { S.E. Asia } \\
\text { Bali } \\
\text { Korea } \\
\text { Japan } \\
\text { Japan } \\
\text { Japan }\end{array}$ & $\begin{array}{l}\text { Unknown } \\
\text { Unknown } \\
\text { Tokushima } \\
\text { Tochigi } \\
\text { Miyagi }\end{array}$ & $\begin{array}{l}1990 \\
1992 \\
1991 \\
1991 \\
1991\end{array}$ & $\begin{array}{l}\text { Coconut } \\
\text { Tobacco } \\
\text { Tobacco } \\
\text { Tobacco } \\
\text { Tobacco }\end{array}$ & $\begin{array}{l}\mathrm{A} 2 \\
\mathrm{~A} 2 \\
\mathrm{~A} 2 \\
\mathrm{~A} 2 \\
\mathrm{~A} 2\end{array}$ & $\begin{array}{l}\mathrm{A} \\
\mathrm{D}^{\prime} \\
\mathrm{D}^{\prime} \\
\mathrm{D}^{\prime} \\
\mathrm{D}^{\prime}\end{array}$ & $\begin{array}{l}\ldots \\
0 \\
0 \\
0 \\
0\end{array}$ & $\begin{array}{c}12.5 \\
108 \\
49 \\
93 \\
110\end{array}$ & $\begin{array}{l}0 \\
0 \\
0 \\
0 \\
0\end{array}$ & $\begin{array}{l}+ \\
- \\
- \\
- \\
-\end{array}$ \\
\hline 405 & Australia & New South Wales & Unknown & Tobacco & $\mathrm{A} 2$ & $\mathrm{~B}$ & 0 & 76 & 1.2 & - \\
\hline 383 & & Queensland & 1988 & Tobacco & $\mathrm{A} 2$ & $\mathrm{~B}$ & 0 & 96 & 0 & - \\
\hline 310 & & Queensland & 1983 & Tobacco & A1 & $\mathrm{D}^{\prime}$ & 0 & 39 & 2.6 & + \\
\hline 316 & & Queensland & 1983 & Tobacco & $\mathrm{A} 2$ & $\mathrm{C}$ & 0 & 42 & 2.2 & + \\
\hline 317 & & Queensland & 1986 & Tobacco & A1 & $\mathrm{C}$ & 0 & 43 & 3 & + \\
\hline 382 & & Queensland & 1988 & Tobacco & $\mathrm{A} 2$ & $\mathrm{~B}$ & 0 & 60 & 0 & + \\
\hline 414 & & South Perth & 1983 & Chamaelaucium sp. & A2 & $\mathrm{D}^{\prime}$ & $\ldots$ & 25 & 0 & + \\
\hline 415 & & Eneabba & 1990 & Banksia leptophylla & $\mathrm{A} 2$ & $\mathrm{D}^{\prime}$ & $\ldots$ & 37 & 4 & + \\
\hline 416 & & Perth & 1991 & Hibiscus sp. & A2 & $\mathrm{A}$ & $\ldots$ & 28 & 4 & + \\
\hline 417 & & Perth & 1991 & Banksia attenuata & A2 & $\mathrm{D}^{\prime}$ & $\ldots$ & 33 & 1.6 & + \\
\hline 418 & & Perth & 1992 & Banksia brownii & A2 & $\mathrm{D}^{\prime}$ & $\ldots$ & 1 & 2.4 & + \\
\hline 419 & & Perth & 1992 & Chamaelaucium sp. & A2 & $\mathrm{D}^{\prime}$ & $\ldots$ & 62.5 & 3.2 & + \\
\hline
\end{tabular}


Line 46-8 harbored the major resistance gene $R l$ derived from $N$. plumbaginifolia and $N$. longiflora. Race 1 isolates infected both lines, whereas race 0 isolates infected only line 46-10.

\section{RESULTS}

Elicitin production in culture filtrates. From the complete collection, a set of 73 isolates (57 from tobacco and 16 from other hosts) with geographic origins spanning all continents was selected (Table 1). Elicitin production in vitro was estimated by SDSPAGE of culture filtrates (data not shown). Of the 73 isolates, 34 produced a protein migrating as parasiticein (the elicitin produced by $P$. parasitica) and serologically related to elicitins (Table 1 ). Parasiticein was produced by all nontobacco isolates $\left(\mathrm{NTE}^{+}\right)$and also by 18 tobacco isolates. This latter group of isolates has already been described from Australia (4) and Europe and Africa (18). The current study confirmed that the classification of tobacco isolates producing $\left(\mathrm{TE}^{+}\right)$and not producing $\left(\mathrm{TE}^{-}\right)$elicitin applies worldwide. Moreover, we observed that $\mathrm{TE}^{+}$and $\mathrm{TE}^{-}$isolates coexist in at least three geographic areas (Queensland, Australia; Bulgaria; and North Carolina, U.S.).

Pathogenicity on tobacco and tomato. The ability of $P$. parasitica isolates to infect tobacco was investigated by a decapitated stem-inoculation assay that allows fast screening of a large number of isolates that previously was especially discriminant (4). Using this technique, isolate virulence, as measured by the length of the stem lesion after 7 days, varied from 1 to $120 \mathrm{~mm}$ (Fig. 1). The distribution of the data was bimodal: 28 isolates had values less than $60 \mathrm{~mm}, 41$ had values greater than $80 \mathrm{~mm}$, and only 4 had values between 60 and $80 \mathrm{~mm}$. This test, however, could be criticized based on the fact that the application of the mycelium on the fresh wound of a decapitated stem gives an initial advantage to the fungus. To test the validity of the stem assay, four isolates of the low-virulence group $(44,316,365$, and 382 , with lesion lengths ranging between 3 and $60 \mathrm{~mm}$ ) and seven isolates of the highvirulence group $(408,329,366,383,384,388$, and 413, with lesion lengths longer than $80 \mathrm{~mm}$ ) were inoculated in a more natural way, by placing zoospores on the unwounded root system of tobacco plantlets. With the former group, mycelium developed around the roots, but there were no observable symptoms after

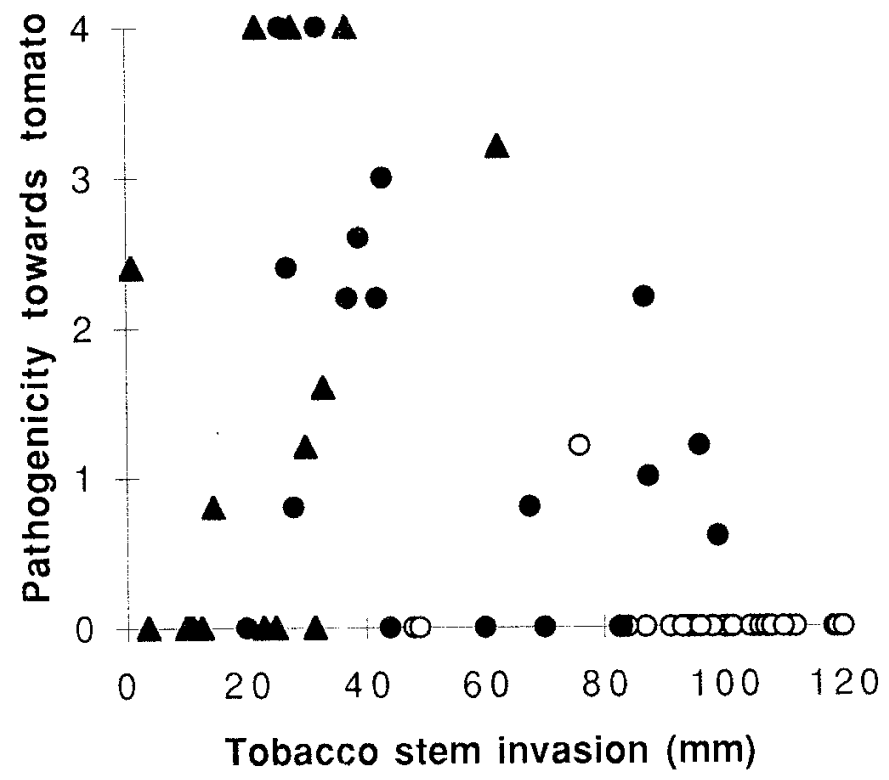

Fig. 1. Pathogenicity of the Phytophthora parasitica isolate collection toward tobacco and tomato. Aggressiveness toward tomato was estimated based on a notation scale of 0 to $4: 0=$ no symptoms and $4=$ death of plant. Isolates were classified as $\operatorname{NTE}^{+}(\mathbf{\Delta}), \mathrm{TE}^{+}(\bullet)$, and $\mathrm{TE}^{-}(\mathrm{O})$, respectively (described in text).
2 weeks, whereas the latter group caused conspicuous symptoms and killed the plantlets. This result indicates that in the stem assay values less than $60 \mathrm{~mm}$ corresponded to isolates non- or weakly pathogenic on tobacco, whereas values greater than $80 \mathrm{~mm}$ corresponded to strongly pathogenic isolates. Most tobacco isolates, but not all, proved strongly pathogenic in this test. Isolate 419 from Chamaelaucium was exceptional, causing 62.5-mm-long lesions on tobacco stems.

The collection also was tested for pathogenicity on tomato, a plant that is a common host of many $P$. parasitica isolates (7). After root inoculation of young plants, 13 isolates proved highly virulent on tomato (notation of 2 or higher), 9 were weakly pathogenic, and 51 were not pathogenic (Fig. 1). No isolate was highly virulent on both tobacco and tomato, but many combined high virulence on one host plant with low virulence on the other plant, indicating that strict host specificity is not a general feature of tobacco isolates.

A remarkable result that emerged from the pathogenicity diagram (Fig. 1) was the distinct distribution of isolates according to elicitin production. In the elicitin-producing $\left(\mathrm{E}^{+}\right)$group, independent of host origin, two-thirds of the isolates could infect tomato, and 13 of 34 had high virulence. In contrast, only one $\mathrm{TE}^{-}$isolate (405) caused symptoms on tomato and only to a very limited extent. Conversely, on tobacco high pathogenicity was the rule for $\mathrm{TE}^{-}$isolates (all but two) and was the exception for $\mathrm{E}^{+}$isolates, with the exception represented by the four tobacco isolates from Argentina (408 to 411) and by one isolate from Zimbabwe (378). Apart from these exceptions, elicitin-producing isolates that were collected on diseased tobacco plants statistically had the same range of pathogenic behavior as those from other host plants, whereas tobacco isolates lacking elicitin production were typically highly virulent on tobacco and nonpathogenic on tomato.

DNA polymorphism within $P$. parasitica. Mitochondrial DNA polymorphism. A previous analysis of the mtDNA of 87 P. parasitica isolates resulted in the distinction of 8 closely related haplotypes (18). Among these, one haplotype (A) was largely pre-

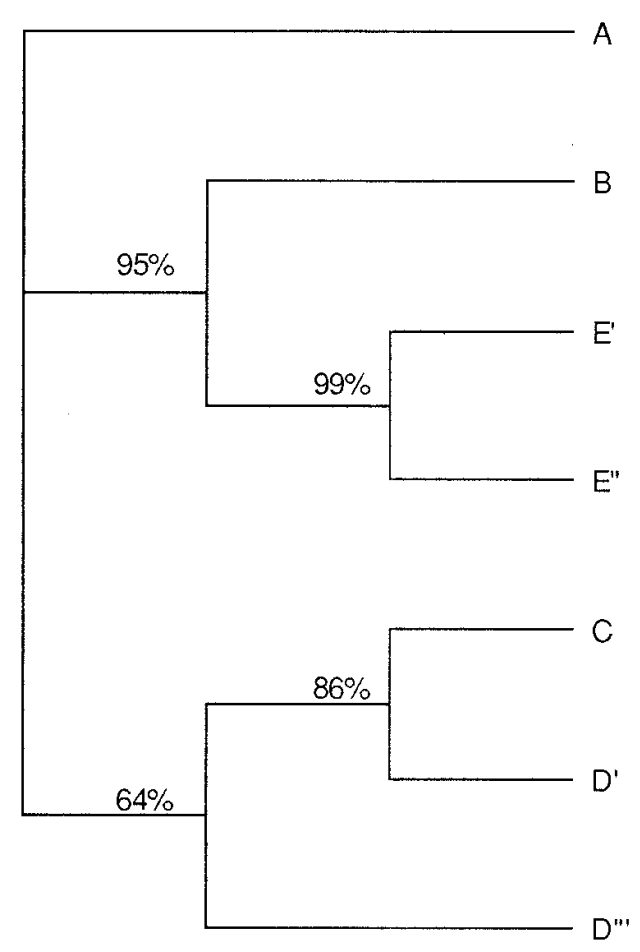

Fig. 2. Most parsimonious tree of mitochondrial DNA polymorphism. Confidence limits of branches (in percents along the branches) were created by bootstrap analysis with 1,000 trials. 
dominant and distributed over all continents, except Australia. No apparent correlation was found between haplotypes and host origin (18). The current study, which focused more on black shank, dealt with 73 isolates: several nontobacco isolates were excluded, and 16 new ones were introduced: 10 from tobacco and 6 from various Australian crops. The determination of their mitochondrial haplotypes did not reveal any new RFLP groups. With the incorporation of these additional data, the relationship between haplotypes and geographic origins (18) could be reassessed. Haplotype A remained prevalent and, in general, was typical of the Northern Hemisphere. Haplotype A was found once in Australia in a nontobacco isolate but not in South Africa or Argentina, where the $\mathrm{D}^{\prime \prime \prime}$ type prevailed. It also was only slightly represented in Southeastern Asia, where the $\mathrm{D}^{\prime}$ type predominated. As previously observed, the minor haplotypes, $\mathrm{B}$ and $\mathrm{C}$, appeared to be indigenous to Australia, because they were found only in Queensland and New South Wales. In contrast, when the distribution of haplotypes was compared with the pathogenicity data, a lack of correlation was revealed.

Phylogenetic relationships between the mtDNA haplotypes were investigated, using both cladistic and phenetic approaches (8). From the parsimony analysis (cladistic method), 12 trees were obtained; all of which were very similar (Fig. 2). All 12 trees separated haplotype A from 2 clusters composed of $\mathrm{B}, \mathrm{E}^{\prime}$, and $\mathrm{E}^{\prime \prime}$ and $\mathrm{C}, \mathrm{D}^{\prime}$, and $\mathrm{D}^{\prime \prime \prime}$, respectively. The only differences between the trees involved changes in the relative positions of the haplotypes within each cluster. The phenograms generated using the UPGMA algorithm (phenetic method), which was available in the Phylip package (8), presented similar topologies (data not shown). Once again, the relative positions of haplotypes $\mathrm{C}, \mathrm{D}^{\prime}$, and $\mathrm{D}^{\prime \prime \prime}$ were uncertain and not validated by a subsequent bootstrap analysis (data not shown). Nevertheless, regardless of the algorithm used haplotype A was always distinct from the two clusters.

Nuclear DNA polymorphism. Nuclear DNA polymorphism was investigated with 25 DNA clones of 0.5 to $3 \mathrm{~kb}$, which were randomly selected from a partial $P$. parasitica DNA library as hybridization probes, and 7 restriction enzymes. The most appropriate combinations were selected based on a small subset of tobacco and nontobacco isolates. Comparative hybridization to total DNA, purified mtDNA, and purified nuclear DNA led to the exclusion of two probes that strongly hybridized with mtDNA. Five probes, corresponding to highly repetitive DNA, produced complex patterns with irregular ladders that could not be used efficiently for RFLP studies. Several other probes produced faint signals due to low levels. Finally, eight probes were used to analyze the whole collection. Five of the probes revealed 1 to 3 bands, two probes revealed 6 to 7 bands, and the probe revealed up to 17 informative bands among the whole population. The RFLP generated by this latter probe is shown in Figure 3. Each probe was used in combination with a single restriction enzyme, leading to eight probe-enzyme combinations. From these combinations, 42 fragments were scored, 32 of which were polymorphic. The reliability of the patterns was verified, as well as their stability when tested on the DNA of distinct monozoospore cultures from several isolates (data not shown). Because we did not have any information about the allelic state of each band scored, we could not rule out the supposition that some markers are linked, so we decided to analyze these RFLP data by a descriptive method, such as FAC $(2,11)$. The pertinence of this method for polymorphism studies has been established previously (6). FAC also allows the inclusion of additional variables (such as host origin, mitochondrial haplotype, and elicitin production) that are not taken into account to describe the population but can be plotted on the same graph as the individuals.

The distribution of the 73 isolates in the factorial planes [1,2] and $[3,4]$ is presented in Figure 4 . Each of the first five axes explains a limited part of the total variability: 16.2, 11.1, 10.0, 9.1 and $9.0 \%$, respectively. This result agrees with the high homoge- neity previously observed in $P$. parasitica $(9,21,22)$. Furthermore, the representation is not biased by any particular marker, because RFLP markers from different random DNA fragments contributed to the determination of each axis.

Some isolates had identical multicharacter patterns and, therefore, shared the same coordinates. In all instances, they also belonged to a single mitochondrial haplotype; however, they often differed in geographic origin, mating-type, or physiological race (for tobacco isolates). This led to a reduction in the number of cases of possible repeated isolation of the same individual in a given area. For instance, the 13 isolates that merged at a single point near -0.4 on axis 1 were collected from tobacco in Greece, Bulgaria, Colombia, Cuba, and in three U.S. states in different years. Nevertheless, as a test the FAC was repeated, using the different genotypes rather than the isolates as individuals, and we found that the general distribution of the population was not modified (data not shown).

Additional variables were included in the analysis: elicitin production, mtDNA haplotype A, and tobacco as host of origin. Elicitin production was strongly and positively correlated with axis 1 , whereas the two latter variables were negatively correlated with the same axis (Fig. 4). These variables have no correlation with the other axes. Essentially, these correlations are due to a group of 28 isolates (including the 13 cited above) that contribute to $50 \%$ of the variability explained by axis 1 and represent the most conspicuous structure within an otherwise apparently homogeneous population. This group is composed solely of $\mathrm{TE}^{-}$cultures that, with one exception (365), belong to haplotype A. If we take into account the results of the pathogenicity tests, we find that these $27 \mathrm{~A} / \mathrm{TE}^{-}$cultures also have in common the fact that they are nonpathogenic on tomato and highly virulent on tobacco (101 \pm $13 \mathrm{~mm}$ ). Throughout the rest of the population, $\mathrm{NTE}^{+}, \mathrm{TE}^{+}$, and $\mathrm{TE}^{-}$isolates of various haplotypes appeared to be intermixed. Nevertheless, another small group of five $\mathrm{TE}^{-}$isolates $(373,374$, 375, 430, and 431, collected in Transvaal and North Carolina, U.S.) were identified. These isolates belonged to haplotype $\mathrm{D}^{\prime \prime \prime}$ and clustered at approximately +0.4 near axis 4 and contributed to $10 \%$ of the variability explained by this axis. Although they are genetically different from the $\mathrm{A} / \mathrm{TE}^{-}$group described above, they have the same pathogenic properties.

In contrast to the observations based on mtDNA polymorphism, isolates from the same geographic area generally were not clustered on the basis of nuclear DNA RFLPs. In Cuba for instance, cocoa isolates of haplotype $\mathrm{E}^{\prime \prime}$ (362 and 364) were very distant from $\mathrm{A} / \mathrm{TE}^{-}$isolates $(324,325$, and 326). In North Carolina, there coexisted three isolates belonging to the large $\mathrm{A} / \mathrm{TE}^{-}$group described above, two $\mathrm{D}^{\prime \prime \prime} / \mathrm{TE}^{-}$isolates $(431,430)$, and one $\mathrm{A} / \mathrm{TE}^{+}(432)$, which are scattered along axis 1 . The same was true for the six $\mathrm{TE}^{+}$isolates from Zimbabwe. The four isolates from Argentina (408 to 411) appeared to be an exception to this rule, because they belonged to a clearly distinct group in the factorial plane [3,4]. Previously they were exceptionally virulent on tobacco $(91 \pm 7 \mathrm{~mm})$ for the $\mathrm{TE}^{+}$isolates.

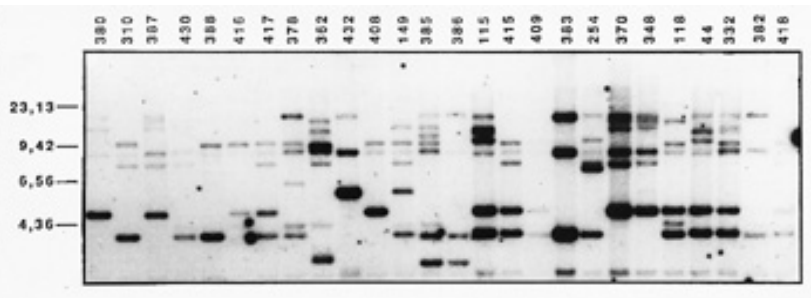

Fig. 3. Nuclear polymorphisms based on probe C1 DNA hybridization patterns among various Phytophthora parasitica isolates (indicated along top). Total DNA $(5 \mu \mathrm{g})$ was digested by HindIII, transferred, and hybridized under stringent conditions (described in text). Size standards (phage $\lambda$ DNA digested with HindIII) are indicated in kilobases to the left. 


\section{DISCUSSION}

This study provides some new insights into the diversity of $P$. parasitica isolates responsible for disease on tobacco. Pathogenicity tests confirmed that a large variation in virulence exists on tobacco, as has been known for a long time (20), and revealed that there may be potential for infection of tomato. A major finding of this study is that the ability or inability to produce elicitin is a feature that delineates the population into two groups that have markedly different pathogenic properties (Fig. 1). $\mathrm{E}^{+}$isolates typically are weakly to moderately virulent on tobacco and are fre- quently pathogenic on tomato. Within the limits of the pathogenicity tests used here, the distribution of these properties does not seem to be statistically different between cultures isolated from tobacco $\left(\mathrm{TE}^{+}\right)$or other host plants $\left(\mathrm{NTE}^{+}\right)$. $\mathrm{TE}^{+}$isolates, thus, appear as polyphagous $P$. parasitica isolates that include tobacco in their host range. In contrast, tobacco isolates lacking elicitin production $\left(\mathrm{TE}^{-}\right)$are characterized by high virulence on tobacco and the absence of pathogenicity on tomato. If we refer to classical definitions in tobacco pathology, the $\mathrm{TE}^{-}$isolates exhibit the characteristics (virulence and host specificity) recognized as belonging to the black shank fungus, whereas $\mathrm{TE}^{+}$isolates generally conform


Fig. 4. Distribution of 73 Phytophthora parasitica isolates analyzed in the current study according to the factorial analysis of correspondence method. Both factorial planes [1,2] and [3,4] are represented. $\mathbf{\Lambda}=\mathrm{NTE}^{+} ; \boldsymbol{\bullet}=\mathrm{TE}^{+}$; and $\bigcirc=\mathrm{TE}^{-}$isolates. Isolates that belong to mitochondrial DNA (mtDNA) group A are indicated in italics. Additional variables are plotted on the graph: $\diamond=$ tobacco as the host $+=$ mtDNA haplotype A; and $*=$ elicitin production 
to the description of the polyphagous strains that cause tobacco brown stem rot in Rhodesia (13). In the current survey, isolates from Zimbabwe (formerly Rhodesia) were all $\mathrm{TE}^{+}$, but this type of isolate also was present in Australia, Bulgaria, the United States, and Argentina. Moreover, the $\mathrm{TE}^{+}$Argentinean isolates (and also one from Zimbabwe) exhibited exceptionally high virulence on tobacco compared to some $\mathrm{TE}^{-}$isolates. Because we have found that all $\mathrm{E}^{+}$isolates secrete similar amounts of elicitin in vitro (data not shown), this observation raises some questions about the role of elicitins as avirulence factors in $P$. parasitica-tobacco interactions. Investigation will be undertaken to determine whether in these isolates elicitin gene expression might be down-regulated in planta, as was recently reported in the $P$. infestans-potato interaction (15).

We examined nuclear DNA RFLPs to study the genetic variability of an extensive isolate collection at a molecular level. To our knowledge, no similar study has been performed previously on such a large sample of $P$. parasitica isolates. Results were analyzed by the FAC method, which appeared especially suitable in this case. Because of the diploid nature of the organism and the lack of information about the Mendelian segregation of the molecular markers considered, analyses normally performed in other systems could not be used in this analysis. The allelic status of the RFLP markers is difficult to determine, because oospores obtained in $P$. parasitica crossings, in general, have a low germination level that precludes correct estimation of the segregation. Moreover single-copy probes did not reveal polymorphisms. The validity of FAC compared to other clustering methods, such as Nei's genetic distance and UPGMA representation, was assessed recently and indicated that similar groupings were obtained with these methods (5). This validation, together with the previous population analysis (6), confirms that the structure obtained in the current study is relevant and indicates that FAC could be a useful alternative in population studies that involve diploid organisms such as Phytophthora.

In this analysis (Fig. 4), the total variability generated by 32 polymorphic fragments was almost equally distributed among several axes. This result, together with the fact that many probeenzyme combinations did not reveal polymorphism, confirms the results of previous studies that indicated $P$. parasitica has an overall lower intraspecific diversity than other Phytophthora species $(9,21)$. Compared to the seven haplotypes defined on the basis of mtDNA polymorphism (18), nuclear DNA RFLP analysis revealed new information about the relationships among isolates. The most prominent result was that one subgroup, represented by 27 isolates in this study, can be distinguished within $P$. parasitica. In addition to their phenetic similarity, based on nuclear DNA RFLPs, these isolates also share a number of other characteristics. In particular, these isolates belong to haplotype A, and they lack elicitin production, come from tobacco, and exhibit high virulence on tobacco. This group encompasses most of the black shank isolates from the United States and probably represents the typical $P$. parasitica var. nicotianae cultures intensively studied there. To our knowledge, this is the first indication that the distinction of these cultures has a genetic basis beyond pathogenicity on tobacco.

This finding supports the previous proposal by Apple (1) that black shank fungus strains arise from rare mutation events in $P$. parasitica that are followed by dissemination. The low variability within the cluster and its position outside the bulk of the other isolates suggests it has evolved from a clonal origin under genetic isolation. Isolation could result from host specificity and the ability of such highly virulent isolates to displace less virulent types (20). Population replacement after migration has been well documented in $P$. infestans (10). Historically, the black shank epidemic in the United States originated in southern Georgia in 1915, invaded Florida, and spread to Tennessee and Kentucky during the next 20 years or so: the first observation of this disease in Puerto
Rico was in 1924 (20). If this reflects the diffusion of a single strain, it may have originated in Central America. This assumption is consistent with the results obtained in the current study, because the Cuban and Colombian isolates occur within the same cluster. Included within this group are some Greek and Bulgarian cultures, which are more likely to be the consequence of a longdistance transportation event from Central America to the Balkans (where the disease was not recorded until 1930), rather than of local adaptation.

The absence of elicitin production could be only one feature among several distinguishing this black shank strain. However, it appears that the 12 other $\mathrm{TE}^{-}$isolates (365 to 388 along axis 1) scattered among the sample display the same peculiar pathogenic properties. For instance, five highly virulent cultures that lacked elicitin production and were collected from tobacco in the United States and Transvaal can be recognized as another cluster. Their position in the factorial planes and different haplotypes precludes the conclusion that they were derived from the same origin as the first group. This observation suggests that the absence of elicitin has a direct connection to the pathogenic behavior of the fungus. Furthermore, information obtained when gathering the culture collection showed that the $\mathrm{TE}^{-}$isolates all came from areas with a long history of tobacco cultivation and severe black shank problems, whereas the $\mathrm{TE}^{+}$isolates came from regions of recent and moderate disease outbreaks. The following scheme may be suggested as a working hypothesis.

A mutation suppressing elicitin production, in one step, would significantly affect fungus biology (16): its general fitness could be reduced (although the elicitin function is unknown, its high conservation suggests it plays an effective role for the fungus), but its specific pathogenicity on tobacco would be increased. The mutated clone would survive and become prevalent in conditions of dominant and repeated tobacco cultivation. These rare mutational events may have occurred several times independently in different genetic contexts within $P$. parasitica and distinct black shank strains.

Two inferences may be derived from this working hypothesis. First, the mechanism leading to the loss of elicitin production would be different in isolates from distinct clusters. Hybridization with elicitin probes did not reveal any pattern specific to $\mathrm{E}^{-}$cultures (data not shown), and investigations are now in progress to unravel the molecular events involved. Second, intensive monitoring of the fungal population in areas where tobacco is exposed to $\mathrm{TE}^{+}$isolates may reveal the emergence of a $\mathrm{TE}^{-}$strain. In fact, such an event may have recently happened in Queensland, Australia. Isolates 382 and 383, both collected in 1988, are phenetically very similar and belong to the rare mtDNA haplotype $\mathrm{B}$. Isolate 382 produces parasiticein and is moderately virulent on tobacco $(60-\mathrm{mm}$-long lesion in the stem test; no infection in the root inoculation test), whereas isolate 383 lacks elicitin, was $96 \mathrm{~mm}$ long in the stem test, and killed plantlets in the root test. If our scheme is correct, a 383-type strain may become prevalent in the region, and the severity of the disease will increase accordingly. To predict disease evolution, similar monitoring could be recommended in regions such as Zimbabwe, where no $\mathrm{TE}^{-}$isolates have been recorded. However, attention also should be given to the ability of the fungus to increase its virulence on tobacco without losing elicitin production, as exemplified by the Argentinean isolates used in this study.

\section{ACKNOWLEDGMENTS}

This research was supported in part by a grant from Région Provence Alpes Côte d'azur. We thank R. Delon, chairman of the Scientific Commission of the CORESTA, for his encouragement and all the pathologists who provided Phytophthora isolates. We also thank C. Boucher (INRA, Toulouse, France), C. Neema and M.-H. Lebrun (Orsay University, France), J. Carlier (CIRAD, Montpellier, France), and L. Lapchin (INRA, Antibes, France) for fruitful discussions and S. Fuller (INRA, Laboratoire de Biologie des Invertébrés, Antibes, France) for proofreading the manuscript. 


\section{LITERATURE CITED}

1. Apple, J. L. 1957. Pathogenic, cultural, and physiological variation within Phytophthora parasitica var. nicotianae. Phytopathology 47:733-739.

2. Benzecri, J. P. 1973. L'Analyse des données. Tome 2, L'Analyse des Correspondances. Dunod, Paris.

3. Bonnet, P., Bourdon, E., Ponchet, M., Blein, J.-P., and Ricci, P. 1996. Hypersensitive-like response and acquired resistance triggered by elicitins in tobacco and other plants. Eur. J. Plant Pathol. 102:181-192.

4. Bonnet, P., Lacourt, I., Venard, P., and Ricci, P. 1994. Diversity in pathogenicity to tobacco and in elicitin production among isolates of Phytophthora parasitica. J. Phytopathol. 141:25-37.

5. Carlier, J., Mourichon, X., Gonzales-de-Leon, D., Zapater, M. F., and Lebrun, M. H. 1994. DNA restriction fragment length polymorphisms in Mycosphaerella species that cause banana leaf spot diseases. Phytopathology 84:751-756.

6. Erselius, L. J., and de Valavieille, C. 1984. Variation in protein profiles of Phytophthora: Comparison of six species. Trans. Br. Mycol. Soc. 83: 463-472.

7. Erwin, D. C., and Ribeiro, O. K. 1996. Phytophthora Diseases Worldwide. The American Phytopathological Society, St. Paul, MN.

8. Felsenstein, J. 1993. PHYLIP (Phylogeny Inference Package), version 3.572. Department of Genetics, University of Washington, Seattle.

9. Förster, H., Oudemans, P., and Coffey, M. D. 1990. Mitochondrial and nuclear DNA diversity within six species of Phytophthora. Exp. Mycol. 14:18-31.

10. Fry, W. E., Goodwin, S. B., Matuszak, J. M., Spielman, L. J., Milgroom, M. G., and Drenth, A. 1992. Population genetics and intercontinental migrations of Phytophthora infestans. Annu. Rev. Phytopathol. 30:107-129.

11. Greenacre, M. J., and Hastie, T. 1987. The geometric interpretation of correspondence analysis. J. Am. Stat. Assoc. 82:437-447.

12. Hall, R., Zentmeyer, G. A., and Erwin, D. C. 1969. Approach to the taxonomy of Phytophthora through acrylamide gel electrophoresis of proteins. Phytopathology 59:770-774.

13. Hopkins, J. C. F. 1956. Tobacco diseases. The Commonwealth Mycological Institute, Kew, Surrey, England, U.K.

14. Hwang, B. H., De Cock, A. W. A. M., Banhweg, G., Prell, H. H., and Heitefuss, R. 1991. Restriction fragment length polymorphisms of mitochondrial DNA among Phytophthora capsici isolates from pepper (Capsicum аппиит). Syst. Appl. Microbiol. 14:111-116.
15. Kamoun, S., van West, P., de Jong, A. J., de Groot, K. E., Vleeshouwers, V. G. A. A., and Govers, F. 1997. A gene encoding a protein elicitor of Phytophthora infestans is down-regulated during infection of potato. Mol. Plant-Microbe Interact. 10:13-20.

16. Kamoun, S., Young, M., Förster, H., Coffey, M. D., and Tyler, B. M. 1994. Potential role of elicitins in the interaction between Phytophthora species and tobacco. Appl. Environ. Microbiol. 60:1593-1598.

17. Kennedy, D. M., and Duncan, J. M. 1995. A papillate Phytophthora species with specificity to rubus. Mycol. Res. 99:57-68.

18. Lacourt, I., Panabières, F., Marais, A., Venard, P., and Ricci, P. 1994. Intraspecific polymorphism of Phytophthora parasitica revealed by analysis of mitochondrial DNA restriction fragment length polymorphism. Mycol. Res. 98:562-568.

19. Le Berre, J. Y., Panabieres, F., Ponchet, M., Denoroy, L., Bonnet, P., Marais, A., and Ricci, P. 1994. Occurrence of multiple forms of elicitins in Phytophthora cryptogea. Plant Physiol. Biochem. 32:251-258.

20. Lucas, G. B. 1975. Black shank. Pages 115-141 in: Diseases of Tobacco. B. C. Associates, Raleigh, NC.

21. Oudemans, P., and Coffey, M. D. 1991. A revised systematics of twelve papillate Phytophthora species based on isozyme analysis. Mycol. Res. 95:1025-1046.

22. Panabières, F., Marais, A., Trentin, F., Bonnet, P., and Ricci, P. 1989. Repetitive DNA polymorphism analysis as a tool for identifying Phytophthora species. Phytopathology 79:1105-1109.

23. Ricci, P., Panabières, F., Bonnet, P., Maia, N., Ponchet, M., Devergne, J. C., Marais, A., Cardin, L., Milat, M. L., and Blein, J. P. 1993. Proteinaceous elicitors of plant defense responses. Pages 121-135 in: Mechanisms of Plant Defense Responses. Kluwer Academic Publishers, Dordrecht, Netherlands.

24. Ricci, P., Trentin, F., Bonnet, P., Venard, P., Mouton-Perronnet, F., and Bruneteau, M. 1992. Differential production of parasiticein, an elicitor of necrosis and resistance in tobacco, by isolates of Phytophthora parasitica. Plant Pathol. 41:298-307.

25. Sambrook, J., Fritsch, E. F., and Maniatis, T. 1989. Molecular Cloning: A Laboratory Manual. 2nd ed. Cold Spring Harbor Laboratory Press, Cold Spring Harbor, NY.

26. Tucker, C. M. 1931. Taxonomy of the genus Phytophthora de Bary. Univ. Mo. Agric. Exp. Stn. Res. Bull. 153:168-176.

27. Waterhouse, G. M. 1963. Key to the species of Phytophthora de Bary. Mycol. Pap. 92:1-22. 